\title{
Corporate social responsibility as cultural meaning management: a critique of the marketing of 'ethical' bottled water
}

\section{Vinicius Brei ${ }^{1}$ and Steffen Böhm²}

1. Management Science Department, Federal University of Santa Catarina (UFSC), Brazil

2. Essex Business School, University of Essex, Colchester, UK

To date, the primary focus of research in the field of corporate social responsibility (CSR) has been on the strategic implications of CSR for corporations and less on an evaluation of CSR from a wider political, economic and social perspective. In this paper, we aim to address this gap by critically engaging with marketing campaigns of so-called 'ethical' bottled water. We especially focus on a major CSR strategy of a range of different companies that promise to provide drinking water for (what they name as) 'poor African people' by way of Western consumers purchasing bottled water. Following Fairclough's approach, we unfold a three-step critical discourse analysis of the marketing campaigns of 10 such 'ethical' brands. Our results show that bottled water companies try to influence consumers' tastes through the management of the cultural meaning of bottled water, producing a more 'ethical' and 'socially responsible' perception of their products/ brands. Theoretically, we base our analysis on McCracken's model of the cultural meaning of consumer goods, which, we argue, offers a critical perspective of the recent emergence of CSR and business ethics initiatives. We discuss how these marketing campaigns can be framed as historical struggles associated with neo-liberal ideology and hegemony. Our analysis demonstrates how such CSR strategies are part of a general process of the reproduction of capitalist modes of accumulation and legitimation through the usage of cultural categories.

\section{Introduction}

Bottled water is one of the fastest-growing industries in the world. The global bottled water market grew by $7 \%$ in 2008 to reach a value of US\$77.6 billion, representing a compound annual growth rate of $6.7 \%$ for the period spanning 2004-2008, which means that bottled water has outperformed the rest of the soft drinks industry (Datamonitor 2009).
In 2013, the global bottled water market is forecast to have a value of US\$106.4 billion, an increase of $37.2 \%$ since 2008 (Datamonitor 2009). Interestingly, most of the growth in bottled water consumption is not observed in developing or poor countries, where tap water is not widely provided and/or its potability is not highly trusted (Water.org 2010, Water for People 2010). On the contrary, the highest figures in per capita consumption are observed in developed 


\section{Business Ethics: A European Review}

Volume 20 Number 3 July 2011

countries, where almost everyone has access to good quality and relatively cheap tap water. For example, Europe alone is responsible for $50.6 \%$ of the global revenues of this market; six out of 10 of the biggest countries in per capita consumption are rich Western European countries, such as the United Kingdom, Italy, France, Germany and Switzerland (Datamonitor 2009).

The global bottled water market has traditionally been characterized by the presence of many regional and local players, although market concentration has been observed for some time. The global market is increasingly dominated by a handful of multinational companies, which have purchased many independent bottled water companies and brands over the past two to three decades. Today, Nestlé $(16 \%)$, Danone $(9.7 \%)$ and Coca-Cola $(7.2 \%)$ share about a third of the global market, and it is these globally operating companies that have made substantial investments into the marketing of their manifold global and regional brands, such as Volvic, Evian, Perrier, to name just three of the best known.

These companies have been facing an increasingly saturated market in the developed world and also growing criticism due to the manifold environmental and social consequences of their business practices waste, packing and transportation pollution, exacerbated consumerism, impact of globalized consumption, etc. (Ecologist 2007, Fox News 2008, Gashler 2008, Which? 2008). As a consequence, many bottled water companies have recently switched their marketing strategies to include themes that can be connected to corporate social responsibility (CSR). More than appealing to 'ethical' consumers only, they are now stimulating 'ethical' consumption by all of their customers through the adoption of marketing strategies that associate their products with ethical actions often situated in the so-called 'developing world.' This is part of a wider trend of cause-related and social marketing (Kotler \& Lee 2005) in the global bottled water and soft drinks industry, which Johnson (2009) says has helped to sustain its growth.

In this paper, we especially focus our critical attention on the type of CSR marketing strategy developed, for example, by Volvic, Danone's bestselling bottled water brand, which has run the campaign 'Drink 1, Give 10' - also called '11 = 101 for Africa' - in its major bottled water consumer markets, such as France, the United Kingdom, Germany, Canada, Japan and the United States. For this campaign, Volvic has teamed up with intergovernmental and non-governmental organizations, such as UNICEF and World Vision, to bring clean drinking water to rural parts of Africa. The idea is that Volvic donates funds to UNICEF and World Vision to provide people in poor African countries with at least 101 of clean drinking water (usually from wells) for each liter of bottled water sold to Western consumers (Just-Drinks.com 2008).

Since 2005, many other bottled water companies have launched very similar CSR marketing campaigns. Although each campaign is different, the basic approach is the same: each bottle of water purchased by a comparatively rich, Western consumer will contribute to deliver drinking water for 'poor African people.' The list of bottled water companies/brands that have been adopting this kind of CSR strategy recently is long: Ethos, Belu, Aquaid, Fairbone Springs, Oasis, One Water, Thirsty Planet, Tumai, Charity Water, to name but a few. That this CSR marketing approach is recognized as being important by the bottled water industry can be seen by the fact that the 2008 Water Innovation Awards (formerly The Bottledwaterworld Awards) included two categories related to this type of strategy - Best Environmental Sustainability Initiative and Best Ethical or Humanitarian Initiative. One might hence say that this kind of CSR strategy is now institutionalized within the bottled water industry.

Most management writers in both the marketing and the CSR fields have been celebrating this linkup of marketing and consumption with specific ethical, social or sustainability causes (e.g. Adkins 1999, Pringle \& Thompson 2001, Wymer \& Samu 2003, Kotler \& Lee 2005, Adler \& AMA 2006). On the face of it, one could see this as a welcome development. As Adkins (1999: 19) predicted more than a decade ago, 'the companies which will sustain competitive success in the future are those which focus less exclusively on shareholders and on financial measures of success and instead include all their stakeholder relationships, and a broader range of measurements, in the way they think and talk about their purpose and performance.' The 


\section{Business Ethics: A European Review}

Volume 20 Number 3 July 2011

cause-related marketing strategies of bottled water companies seem to have proven this prediction right and, at the same time, can be considered an outcome of such advocacy.

However, we argue that, following the work of CSR critics, such as Banerjee (2007, 2008), Shamir (2004a, b, 2005) and Crouch (2006), one must recognize the ethical, economic, social and cultural implications of such CSR strategies. First of all, we are suspicious of the ethical claims made by bottled water companies precisely because many managerialist writers are quite clear about the purpose of the move towards CSR and cause-related marketing: 'consumers report that they would be likely to switch brands or retailers to one associated with a good cause' (Adkins 1999: 83). In short, what Adkins says is that being perceived as 'good' or 'ethical' increases competitive advantage. This, of course, contributes to the 'bottom line,' which leads Banerjee (2008) to claim that the primary focus of research in this area has been on the strategic and economic implications of CSR for the corporation and less on the effects of CSR on society. That is, while the CSR contribution to the 'bottom line' of companies has been clearly established (see Crouch 2006), there has been too little research on how CSR should be understood within a wider historical framework of the development of capitalism and its implications for society as a whole.

Hence, we see our task as critically analyzing the marketing strategies of 'ethical' bottled water companies that claim to be doing the right thing for 'poor people in Africa' by way of selling more bottled water to affluent, Western consumers. Our initial starting point for such a critical approach is Crouch's (2006) claim that it is completely feasible that CSR is simply a (management) fashion for contemporary companies, and it is one of their tactics for creating new ways of selling more goods and services. We will explore this hypothesis in some detail by engaging with McCracken's (1986) model of the cultural meaning of consumer goods (CMCG). If Crouch (2006), Banerjee (2007, 2008) and other critics of companies' CSR approaches are right, then the marketing of 'ethical' bottled water is not so much about delivering 'the good' to poor people in Africa, but more about product differentiation and how to survive in an increasingly competitive soft drinks market in the rich parts of the world. Framing this in a broader historical and sociological way, one could argue that these CSR campaigns are also adopted by companies in order to respond to resistances and critiques expressed by civil society and social movement actors. This 'ethical' turn would thus be a new way of legitimizing capitalist accumulation processes (Boltanski \& Chiapello 2005). Our contribution to the critical study of CSR and marketing is the exploration of this hypothesis through McCracken's (1986) CMCG model, applying it to our specific case of the marketing of 'ethical' bottled water in Western countries.

The paper unfolds as follows: in the next section, we briefly introduce the CSR concept, showing its relation to cause-related marketing campaigns. Next, we discuss the role of marketing in society, focusing on a discussion of McCracken's (1986) model of the CMCG. After presenting our methodological choices, we analyze our empirical data using Fairclough's (1995, 2003) critical discourse analysis (CDA) framework. We finish the paper by discussing the 'ethical' marketing campaigns of bottled water companies from a wider political, economic and social perspective.

\section{Corporate social responsibility}

'CSR' has undoubtedly become one of the most well known and most often used terms recently. As Banerjee (2007: 1) says, 'CSR has become a miniindustry these days both in academia and in the business world.' What is most striking, however, is that it is not only a management or a business term, but one that is also widely used in governmental arenas as well as the non-governmental or the nonprofit sector.

It is therefore not surprising that there seems to be little agreement about what CSR actually is and what precise actions it entails, resulting in a wide variety of attempts to define it (Garriga \& Melé 2004, Wan-Jan 2006, Dahlsrud 2008). Many authors claim that a firm's financial performance depends on positive 'stakeholder management,' the successful cooperation with stakeholders and not just company shareholders (Klick 2009). Kochan \& Rubenstein 


\section{Business Ethics: A European Review}

Volume 20 Number 3 July 2011

(2000) state that one can be considered an important stakeholder as long as one attends to three criteria: (1) they supply resources important to the firm's success; (2) they place something of value 'at risk' their own welfare is directly affected by the firm and outcomes of a project; and (3) they have 'sufficient power' to affect the firm's performance, favorably or unfavorably. Thus, in this example, the term 'stakeholder' is quite tightly defined as someone who is directly influenced by, and linked to, what a company does. More broadly, one could also say that CSR and stakeholder theory sustain that the importance of a stakeholder is determined by its power (the stakeholder's power to influence the company), legitimacy (the stakeholder's relationship with the company) and urgency (the extent to which the stakeholder's demands require immediate attention) (Mitchell et al. 1997, Banerjee 2008).

However, there are also broader definitions of CSR, which are not just focused on companies' most immediate stakeholders. For example, the World Business Council for Sustainable Development (WBCSD) posits that ' $\mathrm{CSR}$ is the continuing commitment by business to contribute to economic development while improving the quality of life of the workforce and their families as well as of the community and society at large' (WBCSD 2010). Equally, Kotler \& Lee (2005: 3) maintain that 'CSR is the commitment of business to contribute to sustainable economic development, working with employees, their families, the local community and society at large to improve their quality of life, in ways that are both good for business and good for development.' The key point here is that wider society and broader aims of development and wellbeing are also seen to be part of the CSR agenda. This is confirmed by Snider et al. (2003: 185) when they emphasize the need for companies to enhance the quality of life of citizens at the global level.

The marketing campaigns by bottled water companies to deliver running drinking water to poor, rural communities in Africa can hence be seen as part of a more general CSR agenda, as it would be difficult to see these distant people as 'stakeholders' who have a direct or even indirect interest, or stake, in these multinational companies. The only way African communities can be seen as stake- holders in the strict sense outlined above is through the consumption of 'ethical' goods by Western consumers who the marketing campaigns of multinational companies are targeted at. That is, the moral obligation and guilt that many people of the West feel for the poverty and under-development of distant people - which is well documented in the literature (Miller 2001, Dolan 2005, Steenhaut \& Van Kenhove 2006, Brennan \& Binney 2010) might be seen as the primary concern of multinational companies.

This leads Snider et al. (2003: 185) to suggest that it is not enough to have a CSR policy on a website. Consumers, they say, increasingly demand examples of concrete 'ethics-in-action,' which is confirmed by the Response (2007) team of researchers, who claim that there has been a shift from a negative conception of CSR (do no harm) to a positive one (do good). That is, while the 1990s and early 2000s could be seen as a time when companies were keen to put glossy CSR material together to show how they do little or no harm, or at least how they are improving their business practices, there is now a move towards putting lofty CSR mission statements into concrete action, actually delivering improvements on the ground.

If Snider et al. (2003) and the Response (2007) researchers are right, then this would confirm the 'political CSR' framework put forward by Scherer \& Palazzo (2007, see also Palazzo \& Scherer 2006, 2008, Scherer \& Palazzo 2008, 2011). Their normative framework, based on a Habermasian understanding of 'deliberative democracy,' argues that CSR should be based on genuine multi-stakeholder regimes, where governments, corporations and civil society actors work together to 'do good' for society as a whole. That is, if CSR is treated politically within a tripartite and genuinely shared setup, then we get away from the widely articulated accusations that CSR is often simply a management fashion (Crouch 2006), an ideological technique for selling more products (Banerjee 2007, 2008) or a manipulative regime for 'greenwashing' (Brennan \& Binney 2008). Scherer \& Palazzo's (2007) framework also deals with the claim that several CSR models are geared towards individuals' responsibilities and 'doing good,' for example, through individual consumption (Fontenelle 2010). 


\section{Business Ethics: A European Review}

Volume 20 Number 3 July 2011

While Scherer \& Palazzo's (2007) 'political CSR' framework is appealing - as it believes in the possibility of multi-stakeholder communities of actors coming together to jointly solve social problems, such as access to drinking water for all - Shamir argues that:

Indeed, 'community' is a key concept in the work of experts who disseminate the corporate-based version of CSR. The 'community' replaces other sociological concepts such as gender, class, and race as a social category toward which CSR efforts should be directed. In fact these latter categories are devoured by the notion of the community in a way that allows for systematic de-politicization of the reasons for becoming 'involved' in communities.

(2005: 106)

For Shamir (2004a, b, 2005), as indeed for Banerjee (2007, 2008), CSR is an ideological distraction from real politics. It is a strategy of de-politicization that 'forgets' the political struggles and antagonisms that characterize social reality (Laclau \& Mouffe 1985). In an interesting paper, Fontenelle (2010) acknowledges this recent struggle by showing how CSR, and particularly CSR marketing and consumption, can be seen as a direct or an indirect response to the 'battle of Seattle', i.e. those anti-corporate social movements that sprang up all over the world at the end of the 1990s to protest against corporate-led globalization. While we would agree with this analysis, which goes beyond Scherer \& Palazzo's (2007) 'political community' approach by emphasizing social struggle - we think it is also important to remember that this very struggle did not start with the 'battle of Seattle' in 1999. There is a much richer and longer history of struggles, involving a wide variety of social movements and other civil society actors (e.g. labor unions, feminists, black and gay rights movements, etc. - see also Spicer \& Böhm 2007), which need to be taken into account when assessing the historical emergence and contemporary politics of CSR.

This is precisely why Shamir (2005) relates the CSR discourse to the struggle for hegemony. He shows how CSR must be understood as the outcome of a particular historical struggle that has increasingly been dominated by neo-liberal movements to the reduction of governmental services and the demise of the regulatory powers of the State (Shamir 2004b). This would be in line with the sociological analysis put forward by Boltanski \& Chiapello (2005), who show how the anti-State and anticorporate resistance movements of the 1960s and 1970s led to the emergence of what they call a 'new spirit of capitalism.' They argue that in response to these movements, this new 'spirit' increasingly emphasized discourses of non-State regulation, community participation and autonomy. According to Boltanski \& Chiapello (2005), in this anti-State and anti-bureaucratic move, marketing played an important role, as it emphasized individual responsibility and power, which was channeled through the act of consumption.

This leads Shamir (2004a) to argue that today's action-oriented CSR approach makes complete business sense from a variety of perspectives. First of all, it can be seen as a 'perfect fit with the neoliberal mode of operation characteristic of many service-oriented civil society organizations that rush to fill the void created by governments that retreat from the supply of public services' (Shamir 2004a: 682). That is, as neo-liberal discourses demand governments to reduce the state-led delivery of public services, privately run companies and nongovernmental organizations increasingly fill this gap by running these services either for or not for profit. Secondly, part of the appeal for companies to engage in CSR activities is internal benefits, which can range from increased employee loyalty and motivation to other internal marketing strategies. As Shamir (2004a: 683) says, 'by focusing on employee participation in CSR projects, by enlisting them to contribute time, money and knowledge, and by sharing with them the company's reputation as socially responsible, the normative control is deployed by transforming employees into a "community" and by turning labor relations into a question of employees' satisfaction and loyalty.' In this way, companies' CSR activities link issues of corporate culture, employee satisfaction and motivation to the brand itself. Just like consumers, employees are also more likely to trust companies and brands if there is involvement with good causes and a corporate commitment to things beyond the 'bottom line' (Kotler \& Lee 2005, Castaldo et al. 2009). What 


\section{Business Ethics: A European Review}

Volume 20 Number 3 July 2011

critics such as Shamir (2004a, b, 2005) and Banerjee (2007, 2008) argue, however, is that this apparent move beyond the 'bottom line' is often carried out with the clear purpose to improve that very 'bottom line.'

\section{Cultural meaning of consumer goods}

Before we discuss the CSR and marketing campaigns of 'ethical' bottled water in more detail, let us first critically reflect more broadly on the role of marketing and consumption in capitalist society. According to Mandel (1975), the basic feature of the contemporary period of capitalism is over-capitalization. That is, due to massive productivity gains derived from innovative production and management technologies, such as mechanization, computerization, process standardization and 'flexible' employee relations, there is always an excess of capital that needs to be reinvested in order to create new profits and capital. Ever new markets are thus created, offering ever new products. The wheel of accumulation, however, only keeps turning if these new products also find buyers. Thus, an expansion of production requires an equivalent expansion of demand; otherwise, capitalism faces an accumulation crisis. One of the most efficient ways to create demand for existing or new products is through marketing (Jameson 1991, Kotler \& Caslione 2009).

In contemporary capitalism, marketing occupies such a central role that one could perhaps say that it often comes even before production. That is, to make sure that even before a product or a service is manufactured or created, there will already be a demand to buy it. This is why Jameson (1991) maintains that capitalist markets are rarely connected to freedom or choice, because our choices are previously 'determined,' and we only choose among the options that companies and institutions provide us. Therefore, the discourse of 'consumer choice' is one that is constrained and prescribed by marketing professionals who manage the CMCG, creating new consumers' tastes and fashions.

The critique of the role of marketing and marketers in the creation and reproduction of consumer culture can be traced at least as far back as the works of Frankfurt School thinkers. Marcuse (1964,
1967), for example, conceptualized the production of false needs by active social agents, and Adorno (1967) showed how advertising transforms a commodity by creating a wide variety of associations and cultural illusions. This early 20th-century scholarship confirms Trentmann's (2009) critique that consumer culture is not something that has only emerged after the Second World War, as so many commentators claim today. What is perhaps less contentious though is the idea of consumer culture generally referring to those relations between social and cultural resources and between symbolic and material resources that are mediated by the market, allowing the recognition of specific social groups through consumption (Arnould \& Thompson 2005).

Marketing is essentially a process of transmutation from a mere material value to something that has, according to Marx's (1976) conception of commodity fetishism, quite extraordinary symbolic powers (see also Böhm \& Batta 2010). In this process, the pure materiality of this good becomes almost unimportant or simply forgotten (Bourdieu \& Delsaut 1987). The creation of a griffe, for example, involves making or merely taking a manufactured product and, without modifying its material nature, transforming it into a luxury good, changing both its economic and its symbolic value. Hence, the circuits of material production and circulation are inseparable cycles of consecration, creating and recreating capitalist relations in society (Böhm 2006).

The key moment in the marketing process is the symbolic transmutation, which is achieved by transforming socially constructed schemes of perception or appreciation (tastes) of existing or potential consumers. Like any symbolic activity, advertising succeeds when it excites or awakens preexisting dispositions, creating opportunities for their recognition and actualization (Bourdieu 2000). But this process should not be understood as correspondence or communicative interaction. According to Bourdieu \& Wacquant, 'it is much more powerful and insidious than that: being born in a social world, we accept a whole range of postulates, axioms, which go without saying or require no inculcating.' Its efficacy is due to the possibility of an 'immediate agreement of objective structures and cognitive structures' (1992: 168). The marketing and con- 


\section{Business Ethics: A European Review}

Volume 20 Number 3 July 2011

sumption process that allows companies to sell products to the wider public is therefore largely unconscious - as explained, for example, through the concept of habitus (Bourdieu 1980, 1984) - which nevertheless implies important politico-economic implications. Therefore, symbolic systems, such as marketing, have a political function as instruments of domination and legitimation of the social order as well as the construction of meaning (Bourdieu 1977, Böhm \& Brei 2008).

McCracken's (1986) seminal three-stage model for the understanding of the CMCG probably represents the most accepted model of the structure and movement of cultural meaning in consumer society. It starts with the idea that at its most basic level, culture is the sphere where the meaning of the world is created. In all cultures, goods are needed primarily for making the categories of culture visible and stable (Douglas \& Isherwood 1996). In contemporary consumer capitalism, this function is largely associated with consumer goods. Miller (1987) argues that societies frequently consider objects as having attributes, which may not appear evident to outsiders or, in contrast, they ignore attributes that might be inextricably part of that object to these same outsiders. This phenomenon is one of the manifestations of the CMCG model. McCracken's (1986) model claims that cultural meaning is located in three places: the culturally constituted world, the consumer good and the individual consumer (see Figure 1).

McCracken's (1986) framework establishes two major steps of meaning development and transfer in which institutions or rituals work as bearers of the meaning of consumer goods. The first step involves advertising and fashion systems; the second involves consumer rituals. In order to become resident in consumer goods, advertising works as an instrument of meaning transfer when it brings together the consumer product or service and the culturally constituted world within the frame of one particular piece of advertising. McCracken (1986) maintains that this symbolic equivalence is developed by the advertising agency, which succeeds when the viewer/ reader attributes to the consumer good certain properties he or she knows existing in the culturally constituted world. When this happens, the meaning transfer process is complete. The fashion system works along similar lines as the advertising system. Figure 1: McCracken's (1986: 72) movement of meaning
model

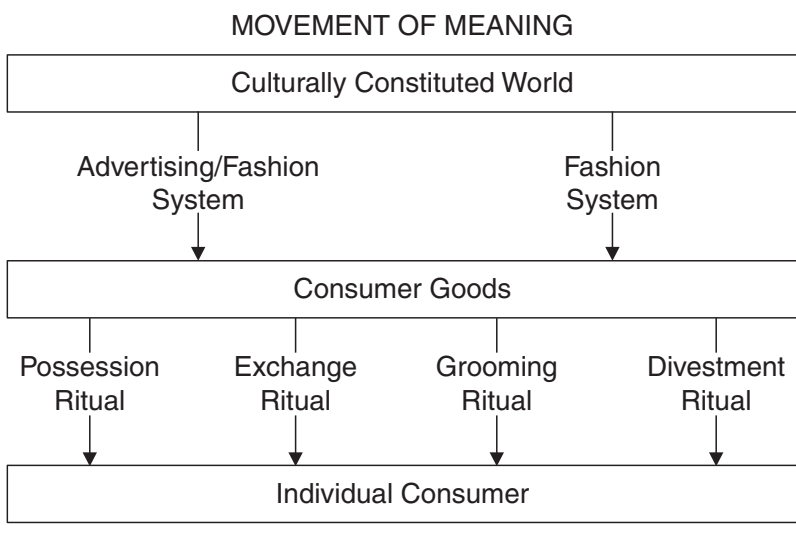

KEY: Location of Meaning

Instrument of Meaning Transfer

The second set of instruments of meaning transfer is consumer rituals. There are four major ones. First, exchange rituals occur when someone chooses, purchases and presents goods to others, for example, during Christmas, Valentine's Day or birthdays. Second, possession rituals are manifested when one spends time cleaning, discussing, comparing, reflecting, showing off and photographing one's goods. Third, grooming rituals are the special pains necessary to ensure that the special, perishable properties resident in the good are captured and made resident in the individual. This happens, for example, when one is dressing for a special party or dining event, and one chooses certain make-up, hair style, clothes, etc. according to the importance of this moment. Lastly, divestment rituals are those in which one tries to erase the meanings associated with previous owners (e.g. cleaning, painting or reforming newly acquired goods), and even the disposal of a consumer product.

McCracken's (1986) framework is arguably providing an important insight into the concrete and specific workings of consumer society in contemporary capitalism. It provides us with tools for understanding how meaning is attached to consumer goods that go beyond utilitarian functions. As we will see, this becomes of importance for understanding the workings of CSR and marketing campaigns of 'ethical' goods, such as those carried out by bottled water companies. In our case, the 
question is how ethical meanings of aid for African people are 'added on' to a utilitarian and basic good such as drinking water. However, before we answer this question, let us first introduce our methodological approach and then present a range of data that will form the empirical background of this study.

\section{Method}

The first step in our empirical research of the marketing campaigns of 'ethical' bottled water brands was to choose which precise brands to investigate. We began our search of the market by studying the 'Ethical buyer's guide to bottled water' by the Ethical Consumer Magazine (2006) (see Figure 2).

We then investigated the websites of each of the 21 water brands presented in Figure 2. Our goal was to find which of them had specifically developed ethical campaigns in relation to providing drinking water to African people, as we decided this to be our empirical focus. Four brands met this criterion: Belu, Aquaid, Ethos and Volvic. As Ethical Consumer is a UK-based magazine, we extended our search using Google, applying keywords such as 'bottled water campaign Africa,' 'water Africa aid,' 'bottled water Africa' and so on. Using this method, we found a number of other bottled water brands: Fairbone Springs, Oasis, One Water, Thirsty Planet, Tumai and Charity Water. Thus, our final list of companies comprised 10 bottled water brands (see Table 1) that have developed similar campaigns to provide drinking water to Africa. For each of these 10 brands, we have collected as much information as possible, mainly though the companies' websites or from any other available source on the Internet. For some of them, mostly Volvic, we have also collected primary data on the streets of major cities in the United States (Chicago) and France (Paris).

We have then analyzed all collected data - which constituted our corpus of data - using a discourse theoretical methodological approach. In accordance with discourse theory, all data were treated as text (Phillips \& Hardy 2002). That is, following a discourse theoretical methodological framework, texts should not be treated in isolation from each other, because they acquire meaning only in their connection with other texts, through their production, distribution and
Figure 2: Ethical buyer's guide to bottled water

\begin{tabular}{|c|c|}
\hline Brand & Rating \\
\hline Belu bottled water [S] & 16 \\
\hline Frank bottled water & 15 \\
\hline Aquaid bottled water & 14 \\
\hline $\begin{array}{c}\text { Cool Water bottled } \\
\text { water }\end{array}$ & 13 \\
\hline Deeside bottled water & 13 \\
\hline $\begin{array}{l}\text { Harrogate bottled } \\
\text { water }\end{array}$ & 13 \\
\hline $\begin{array}{l}\text { Lakeland Willow bottled } \\
\text { water }\end{array}$ & 13 \\
\hline Findlays bottled water & 11.5 \\
\hline $\begin{array}{c}\text { Strathmore mineral } \\
\text { water }\end{array}$ & 11.5 \\
\hline $\begin{array}{c}\text { Highland Spring bottled } \\
\text { water [O] }\end{array}$ & 10 \\
\hline $\begin{array}{c}\text { Pennine Spring bottled } \\
\text { water }\end{array}$ & 10 \\
\hline Ethos bottled water & 4 \\
\hline Evian bottled water & 4 \\
\hline Malvern bottled water & 4 \\
\hline Shape bottled water & 4 \\
\hline Volvic mineral water & 4 \\
\hline Aqua-Pura bottled water & 2 \\
\hline Buxton bottled water & 0.5 \\
\hline Perrier bottled water & 0.5 \\
\hline $\begin{array}{c}\text { San Pellegrino bottled } \\
\text { water }\end{array}$ & 0.5 \\
\hline Vittel bottled water & 0.5 \\
\hline \multicolumn{2}{|c|}{$\begin{array}{l}\text { The higher the rating the more ethical the brand } \\
\text { This whole scorecard was last updated from our } \\
\text { database on } 14 \text { October } 2009 \text { but some } \\
\text { individual company ratings may have changed } \\
\text { since then. Up to the minute information can be } \\
\text { seen by subsribers using Ethiscore. Learn } \\
\text { more about our ratings. }\end{array}$} \\
\hline
\end{tabular}

Source: Ethical Consumer Magazine (2006). 


\section{Business Ethics: A European Review}

Volume 20 Number 3 July 2011

reception, forming textual and discursive structures. It is this structured meaning that creates social effects, not the individual text itself (Fairclough 1995, 2003).

We have chosen CDA, based on Fairclough's (1995, 2003) framework, as our methodological strategy. Fairclough's CDA framework comprises three levels of analysis. First, we have carried out a textual analysis, bearing in mind that texts can involve spoken words, photographs, speeches, websites, bottle adverts, etc. This level of analysis is largely descriptive to gain an insight into the richness of the empirical base. This is why we have identified, codified and described the different texts bottled water companies produced throughout the 10 different marketing campaigns. Our goal in this phase was to describe this corpus as clearly as possible to understand the discursive strategies developed by each of the campaigns.

Second, we have developed a process analysis, in which we have read across different texts, analyzing their discursive practices, especially their production, distribution and interpretation. This phase is aimed at understanding the entire cycle of the campaigns, that is, how the different representations of water were materialized through multiple marketing efforts. Unfortunately, we were not able to study the reception of these marketing discourses in detail, as we did not have the resources to collect primary data in a variety of different markets around the world.

Third, and this is the most important level of the analysis, we have carried out a social analysis, which studies the bottled water campaigns as a discursive system or an 'order of discourse' that produces very specific discursive practices using particular discursive strategies (Foucault 1969, 1971). This 'order of discourse' involves wider social, political, cultural and economic practices, which, we argue, help to transform the cultural meaning of bottled water and their relative success in the marketplace.

\section{The meaning construction of 'ethical' bottled water}

Table 1 provides a detailed overview of the marketing strategies adopted by the 10 brands we studied in our empirical research of the bottled water market.
Textual analysis: buy from us and we will help them

The 10 brands's marketing campaigns we studied showed many similarities. The basic structure of the offering is roughly the same for all them: the brand and bottled water company are always based in a rich and developed country, while the beneficiaries are people who lack drinking water in poorer, developing countries. Our empirical research focus was particularly on Africa, but the beneficiaries of these campaigns are also located in many other countries in Asia and Latin America. The 'business model' is always the same: if consumers in rich, developed countries buy bottled water, then companies will provide or help to provide drinking water to African people and communities. In the marketing documentation, there is always a brief explanation of the basics of how this process works and why it is important, while companies are eager to textually and visually link their bottled water brand to the campaign that promises to provide drinking water to poor people.

Sometimes, the company is very clear about the actual quantities that will be donated. For example, one bottle of Ethos water results in five cents for programs in Africa; 11 of Volvic bottled water means 101 of drinking water for Africans; Thirsty Planet maintains that its customers know exactly how much money is being donated to the charity at the time they buy the product: 'It only costs $50 \mathrm{p}$ to give someone clean water for life!' But this proportion is not always clear, as some brands are less precise about the relationship of bottled water sold and the amount of aid given to Africans. For example, The One Foundation - the charitable division of Global Ethics, an organization that sells and markets 'One' branded products in order to generate funds for humanitarian projects in developing countries - only states that 'a portion' of sales from the One brand of bottled water sold at its UK World Duty Free airport outlets is donated to African countries.

In the companies' marketing material, Africans are predominantly portrayed as poor, helpless and passive; images almost always include children and women exclusively. Some companies, such as Volvic, provide comparative figures for the average water 


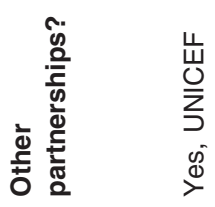

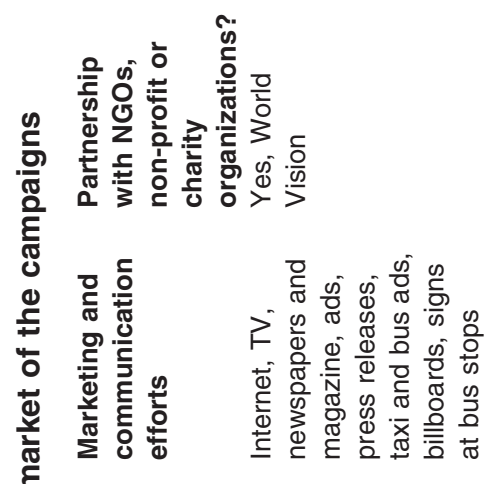

음

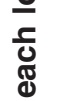

ठ 青

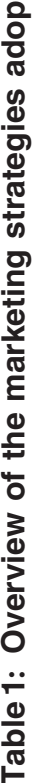

$\bar{\Phi}$

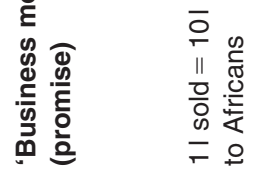

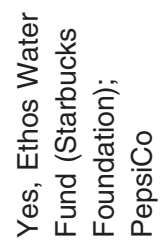

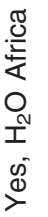

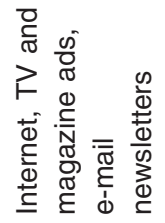

$\stackrel{\infty}{\infty}$

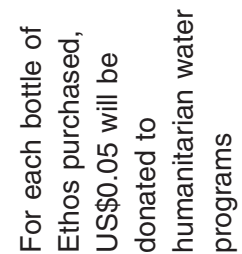

ष্

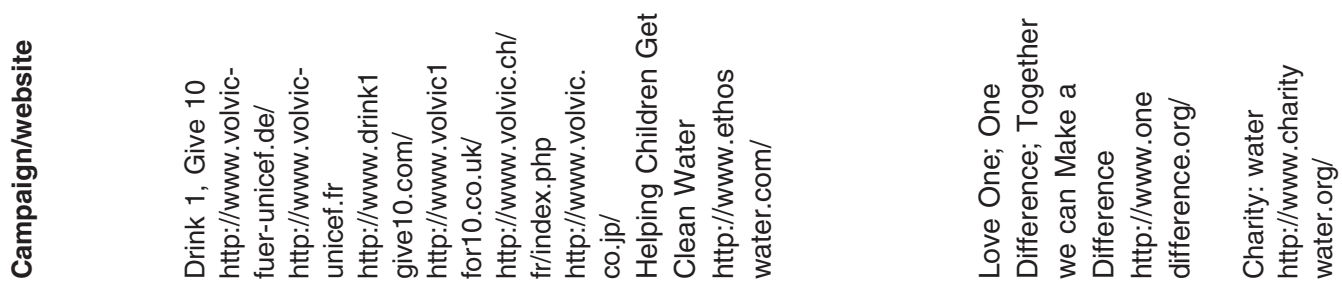

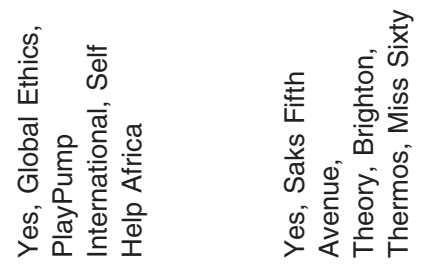

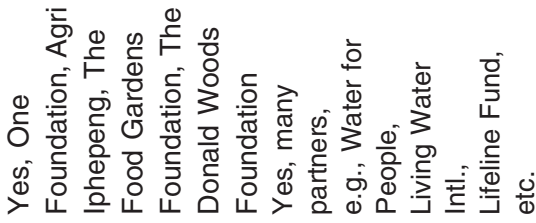

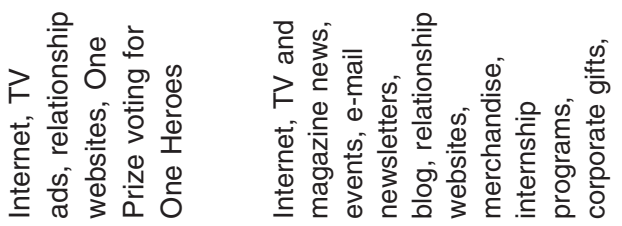

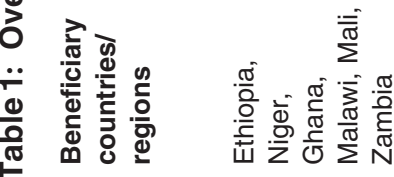

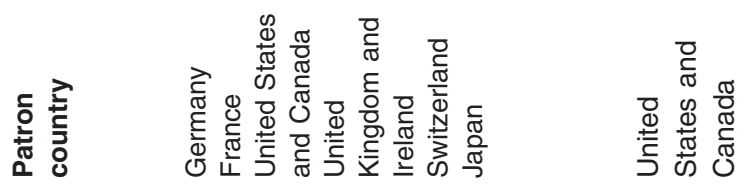

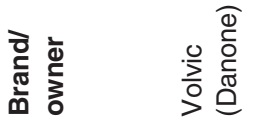

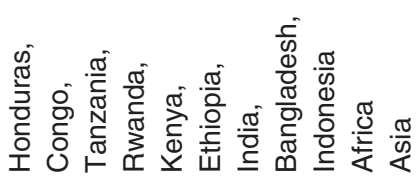

우

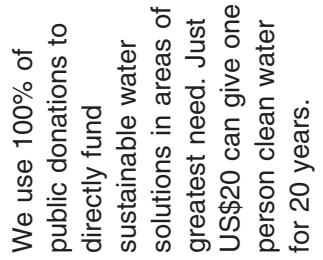

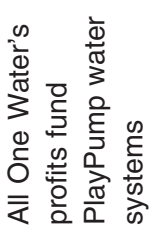

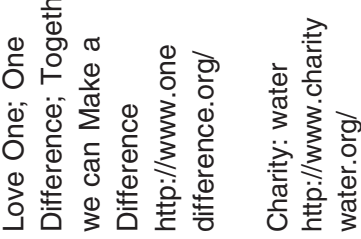




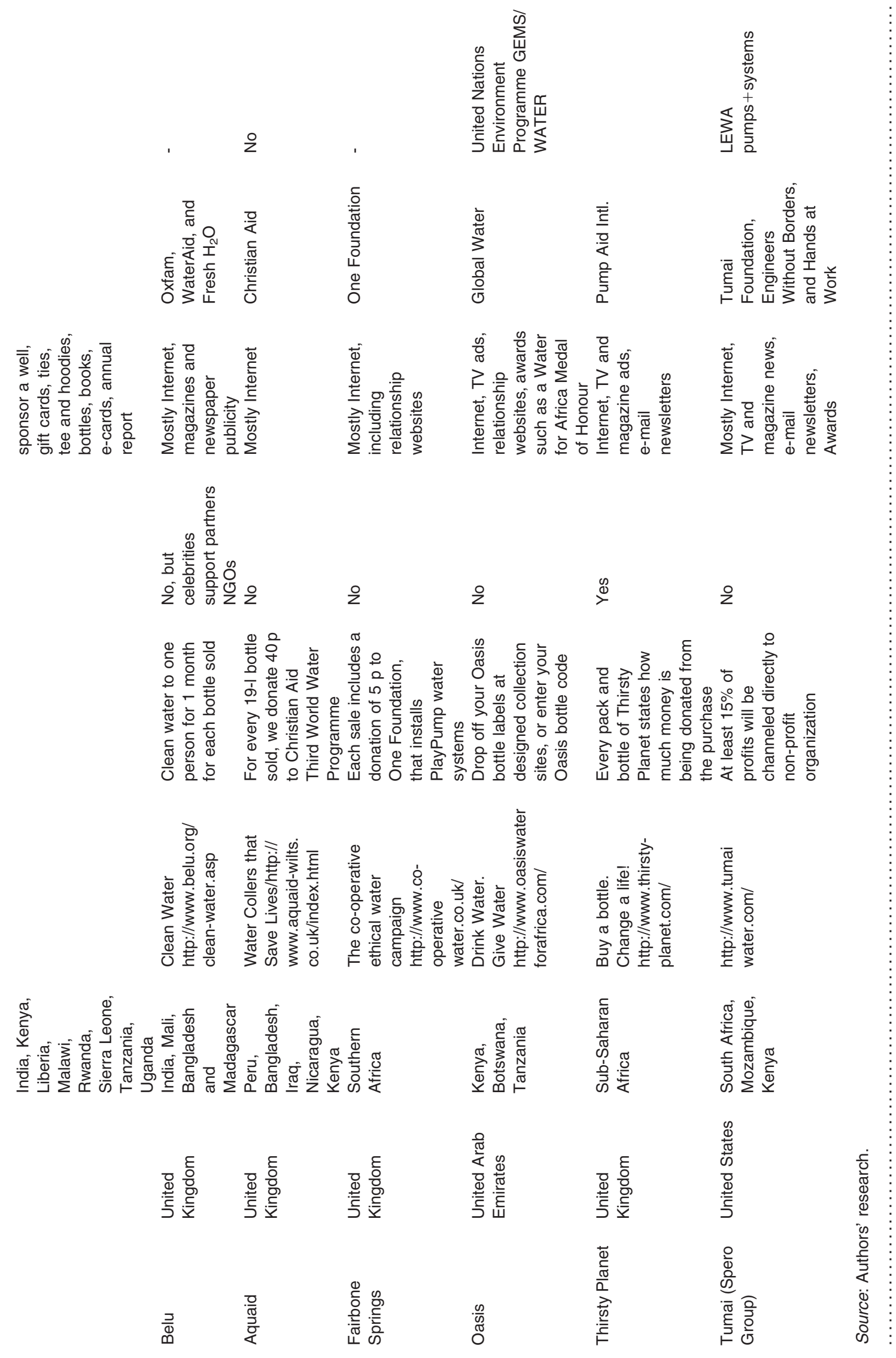




\section{Business Ethics: A European Review}

Volume 20 Number 3 July 2011

consumption in 'developed' and 'developing' countries, which, of course, show an enormous difference, presumably resulting in emotional feelings among bottled water consumers in the rich world. The slogans of most of the campaigns help to arouse such emotional feelings: 'Drink 1, Give 10' (Volvic), 'Helping Children Get Clean Water' (Ethos), 'Love One; One Difference; Together we can Make a Difference' (One Water), 'charity: water' (Charity Water), 'Water Coolers that Save Lives' (Aquaid), 'The co-operative ethical water campaign' (Fairbone Springs), 'Drink Water. Give Water.' (Oasis) and 'Buy a bottle. Change a life!' (Thirsty Planet).

The text and images of the campaigns are always emotional and persuasive, trying to closely connect the bottled water consumer to the African problem of lack of water. The campaigns urge consumers to 'get involved' and 'participate' in solving this problem by buying a bottle of branded water. Many of the companies have formed partnerships with other organizations, such as UNICEF, WaterAid and other NGOs, non-profit, development and charitable organizations. On most water bottles, the logos of these non-commercial organizations are closely located next to the brand logos of the bottled water companies. Some brands - for example, Volvic, Ethos, One Water, Thirsty Planet and Belu - have also involved spokespeople, usually a celebrity, to act as the campaign's godfather or godmother.

In short, the textual analysis of our corpus shows that the discursive strategies developed by each of the ethical marketing campaigns try to connect the bottled water brands to the idea of helping poor people, particularly women and children, in African countries in partnership with reputable non-profit organizations and celebrities.

\section{Process analysis: the production, distribution} and interpretation of the marketing campaigns

We begin with the geographical scope of the campaigns, which varies significantly. Some brands (e.g. Fairbone Springs) are focused on only one 'developed' country, while implementing their aid projects in only one 'developing' country. Other campaigns (e.g. Volvic), however, are based in multiple 'developed' countries that also benefit multiple African countries.

Despite these differences in scope, the production and distribution of the campaigns follow similar structures. First, all target markets/consumers are located in high-income 'developed' countries. Second, the marketing efforts aiming to 'distribute' the campaigns use visually strong media channels, such as Internet websites, TV spots, newspaper and magazine ads, taxi and bus ads, billboard ads, bus stop ads, e-mail newsletters, etc. They also include merchandising, internship programs, corporate gifts, sponsoring of events, awards to buyers and even gift and e-cards, ties, hoodies, bottles and books related to the campaigns. In short, the complete marketing machinery has been pulled out, so to say, in order to spread the word about these 'ethical' campaigns.

Third, most of the brands name a spokesperson usually a celebrity - who acts as godmother/father or ambassador for the campaign, engaging in a range of media stunts. Fourth, all campaigns explicitly encourage consumers to participate directly in the campaigns. The main call for participation is, of course, channeled through the act of buying the bottle of water, although the term 'buy' was rarely used. Instead, words such as 'participate,' 'collaborate' and 'donate' were highlighted. Yet, this participation is also encouraged in non-financial ways, as consumers can send Internet messages about the campaign to friends, write testimonials and contribute to the campaigns' online diary. As Kotler \& Lee (2005) argue, by linking their products to a wider social aim, a cause, companies hope to persuade consumers to participate in something larger than a simple commodity-purchasing act.

Fifth, probably due to the growing criticism of the environmental impact of bottled water consumption, which can be noted in many 'developed' markets (Ecologist 2007, Fox News 2008, Gashler 2008, Which? 2008), companies explicitly link their brands with claims of being 'ethical' and 'green.' For example, Belu (2010) water nominates itself as 'the UK's most eco-friendly bottled water.' Sixth, the distribution of the discourse is strengthened by partnerships with one or more non-profit organizations, such as UNICEF, World Vision, World Water, PumpAid, etc. These organizations themselves have strong symbolic capital, which the 


\section{Business Ethics: A European Review}

Volume 20 Number 3 July 2011

bottled water brands are eager to associate themselves with.

Finally, the bottles' labels are heavily used for the marketing of the campaign. Besides the obligatory information that must be provided by all bottled water companies (chemical composition, company data, etc.), which varies slightly from country to country, the labels usually include the logos of the bottled water brand and the non-profit organization, the campaign's title and/or slogan, a brief instruction of how it works, a short persuasive textual message, stimulating the customer to participate, and one or a few images that complement the persuasive textual messages (e.g. an Africa map, photos of poor children, images representing the shape of a human heart, etc.). The bottles themselves are usually available in high-income towns/neighborhoods, and in places where customers who are perhaps more concerned, or at least more informed, about Africa's problems, such as at airport duty-free shops.

\section{Social analysis: CSR and the historical construction of the cultural meaning of bottled water}

After presenting textual and process analyses of the 10 different ethical marketing campaigns we studied, let us now analyze how the different elements add up to create an overarching discourse, which, although not developed and implemented by one company or brand alone, does constitute, in our view, an overall order of discourse (Foucault 1969, 1971) that aims to transform the cultural meaning of bottled water.

As Banerjee (2007, 2008) clearly shows, companies' CSR strategies and practices should not be seen in isolation from wider cultural, political, economic and social relations. That is, the dynamics of power between corporations, governments, international institutions, NGOs and other social groups produce a particular form of political economy as well as the conditions and norms for participating in that economy. Hence, as Scherer \& Palazzo (2007) rightly say, most of the CSR literature, which is so concerned with discussing the implications of CSR for corporations, misses the point. What is needed, instead, is the broadening of the unit of analysis from the individual firm to the political networks of relations between different market, state and non-state actors that constitute society and its political economy.

Of course, CSR and stakeholder theory is, in some ways, a broadening of the unit of analysis, as the firm's financial performance is now seen to depend on positive 'stakeholder management' (Klick 2009) rather than simply 'shareholder management.' However, there are clearly limits to this process of broadening, which lead Scherer \& Palazzo (2007) to argue for a 'political CSR' approach, bringing together corporations, governments and civil society actors in a genuine tripartite issue-solving community. The 'ethical' bottled water campaigns we have studied could be seen as exemplary cases for the workings of Scherer \& Palazzo's (2007) 'political CSR' framework, as different sectors (corporations and NGOs) have come together to solve specific and important problems concerning the provision of basic services in poor African countries. While we would not want to belittle the good work that can indeed be done through such channels, it is also important to understand the historical contexts of struggles and wider social and economic implications of Scherer \& Palazzo's (2007) preferred political community approach.

As Fontenelle (2010) shows, CSR needs to be seen within a wider historical development of struggles and resistances, which has seen many anti-corporate and so-called 'anti-globalization' movements expressing their disquiet about the negative social, economic, cultural and environmental implications of capitalist consumerism and the economic growth mantra since the late 1990s. The CSR campaigns we have studied should hence be understood as part of a general corporate response to such critiques and resistances by civil society actors. As we discussed above, there have been manifold claims recently that the extraordinary growth of the bottled water market has important environmental implications, as mountains of plastic waste and $\mathrm{CO}_{2}$ emissions are produced through the global production, distribution and consumption of bottled water, despite the fact that most Western consumers - who are the primary audiences of these marketing campaigns have access to safe and cheap drinking water through their taps.

Going beyond Fontenelle's (2010) argument, Shamir (2004b, 2005) highlights the need to see 


\section{Business Ethics: A European Review}

Volume 20 Number 3 July 2011

such CSR strategies as the outcome of much wider historical struggles, involving neo-liberal political and economic moves to continuously privatize State provisions of basic services, such as access to drinking water, throughout the world. As Otto \& Böhm (2006) and many others have shown, the private sector often profits immensely from these privatized public services, often resulting in economic and social hardship particularly among poorer communities in developing countries. The moral obligation and guilt that CSR and ethical marketing campaigns arouse in rich, Western consumers, therefore, has to be seen within a wider frame of neo-liberal political economy, which has contributed to the production of a crisis of access to safe drinking water over the past three to four decades.

This leads Shamir (2004a, 2005) to see CSR as a 'de-radicalization' or even a 'de-politicization' strategy. That is, the cause-related marketing strategies of the bottled water brands we have studied and Scherer \& Palazzo's (2007) community approach can be understood as a distraction away from the engagement with political struggles around issues of class, inequality and development as such (Banerjee 2007, 2008). Thus, we argue that, rather than celebrating the good causes that ethical marketing and CSR support, we have to frame them in a bigger picture that should consider not only the financial and non-financial interests of companies, state and non-state actors that are tied up with these bottled water campaigns. Indeed, we argue that they must be framed within wider historical struggles associated with neo-liberal ideologies and the hegemony of capitalist development (Laclau \& Mouffe 1985). While such critiques, although in their minority, are now well established through the work of Banerjee (2007, 2008), Shamir (2004a, b, 2005) and others, what we would like to add to this debate is the idea that CSR is being actively used by companies to shape the meaning of consumer goods, strategically repositioning products within increasingly competitive markets, such as the bottled water market. Let us now explore this argument in more detail.

Bottled water is essentially a banal product. It is something that has no special physical or chemical attributes if compared with the good-quality tap water that is available in most of the developed world for often hundreds of times less than the price of water sold in bottles. To our knowledge, no serious research to date has proven that one will have any kind of additional physical benefit by drinking water bought in bottles. Thus, the role of marketing in the bottled water industry is of foremost importance, as advertisers need to explain to consumers why they should spend significant amounts of money on a good that is often freely available or, at the minimum, very cheap to obtain. It is precisely this process of the social and cultural construction of the meaning of a product that we explore in this paper, using the example of the ethical marketing of bottled water.

The ethical marketing campaigns we have studied are essentially aimed at transforming the symbolic value - that is, the cultural meaning - of water without modifying its material nature. These campaigns - mostly through advertising - try to affect the psychological aspect of consumption as they are aimed at influencing the constructed schemes of perception and appreciation (tastes) of existing and potential consumers (Bourdieu 2000). It is a symbolic transmutation of the cultural meaning of water, which is being gradually transformed from a banal, life essential good into a consumer product that connects to a range of different cultural images of aid, development, environmentalism, etc. In this way, the ethical marketing of bottled water is an example of what Hirschman et al. (1998) call the transformation of products and goods as material entities into something meaningful through the process of attaching signifiers of culturally recognized practices or categories.

Our argument is that marketing efforts could have constructed other cultural meanings besides the ones associated with the campaigns of delivering drinking water to poor, rural communities in Africa. These campaigns 'make sense' within a wider political economy that has increasingly become influenced by accumulation and legitimation processes structured around the signifiers 'CSR' and 'stakeholder management.' As we have argued above, this process itself must be seen as part of a history of neoliberalization that is characterized by the increasing withdrawal of the State from the regulation of markets and the provision of core public services, such as the delivery of drinking water. The construction of the particular meaning system that 


\section{Business Ethics: A European Review}

Volume 20 Number 3 July 2011

we look at in this paper, therefore, does not come out of nowhere. It is intrinsically linked to a particular history of capitalist development of accumulation and legitimation, which, as Boltanski \& Chiapello (2005) show, has undergone and is continuing to undergo significant changes.

The question is, then, how exactly the meaning of bottled water is constructed in the specific case of the ethical marketing campaigns we have studied. We have found McCracken's (1986) theory of the construction of the CMCG very useful in this regard. For McCracken (1986), the task of advertising and marketing is to attach specific cultural categories to goods, products and services, which can then be sold in the marketplace. Hence, the role of advertising and marketing is to excite and awake pre-existing cultural dispositions in individual consumers in the hope that they will be recognized and actualized through the act of consumption (Bourdieu 2000). One of the most important ways in which cultural categories are substantiated is through a culture's material objects (see, e.g. Goffman 1951, Sahlins 1976, Levy 1981, Hirschman 1984). By attaching images of 'ethics,' 'aid' and 'development' - or even 'love' - to consumer products, such as bottled water, underlying cultural assumptions are substantiated and materialized. This is how these categories create a 'system of distinctions that organizes the phenomenal world,' as 'each culture establishes its own special vision of the world, thus rendering the understandings and rules appropriate to one cultural context preposterously inappropriate in another' (McCracken 1986: 72). Thus, the act of consuming bottled water becomes the material expression of a cultural disposition through which one can articulate one's desires for ethics, charity, help, and, more generally perhaps, a better world.

This process of the construction of meaning should not be seen simply as something that is done by corporations, or any other institution of authority, although their role and power is, of course, significant. The consumer, as individual and social group, is an important participant in the process of the development of cultural meaning (Williamson 1978). McCracken (1986) argues that consumer rituals are essential for the construction of the CMCG (Applbaum \& Jordt 1996), as the consumer 'must complete the work of the [advertising] director' (McCracken 1986: 75). This is why we could identify many efforts by the bottled water companies - besides the obvious goal of selling more water - aimed at stimulating specific consumer rituals.

The first kind of consumer ritual that McCracken (1986) identifies is exchange, that is, when someone chooses, purchases and presents goods to others. Many of the ethical marketing campaigns we studied are designed to become a talking point in wider society. Companies are very keen, for example, to use social networking sites to create discussion and exchange possibilities among Internet users. The use of celebrities is also geared towards generating publicity and improving the exchange potential. Hence, the media (traditional print media as well as new media in the form of Internet sites) play a crucial role for generating interest and facilitating the exchange ritual during the pre-purchase and after-purchase stages of the consumer decision process.

The second kind of consumer ritual - possession, manifested when one spends time cleaning, discussing, comparing, reflecting, showing off and photographing his or her goods - is also highly relevant for the ethical marketing campaigns we have analyzed. Volvic, for example, tries to involve consumers in its campaign by inviting them to post their pictures onto a website, contribute to the campaign's diary and pass the website's address, videos, testimonials and messages to friends. The use of labels is also of significance for the possession ritual. By extensively using the bottle labels for the exposition of the ethical message and the outline of the aid and development project, companies give consumers a chance to materially possess a part of the campaign. That is, by buying the bottle of water, consumers can feel part of something good and worthwhile, while also being able to show off their ethical credentials to friends and peers.

The third of McCracken's (1986) consumer rituals - grooming, that is, the special pains necessary to ensure that the special, perishable properties resident in the good are captured and made resident in the individual - was less observed in the campaigns we have analyzed. This is because bottled water is not necessarily seen as a luxury good, although there are indeed water brands that can be seen in this 


\section{Business Ethics: A European Review}

Volume 20 Number 3 July 2011

category. For example, Bling $\mathrm{H}_{2} \mathrm{O}$ is a luxury bottled water brand that was created in 2005. Each $375 \mathrm{ml}$ Bling $\mathrm{H}_{2} \mathrm{O}$ bottle is exclusively sold in a few luxury stores for up to 50 euros. The bottles are produced with hand-made Swarovski crystals to be consumed by 'Hollywood stars' and 'selected athletes and actors.' As its creator said, in Hollywood 'people carried their bottle of water as part of their personal presentation.' The Bling $\mathrm{H}_{2} \mathrm{O}$ advertising discourse claims it is a 'haut-couture' water that has been 'launched like the Rolls Royce Phantom' and that 'it is not for everyone' (Bling $\mathrm{H}_{2} \mathrm{O}$ 2006). Thus, one could imagine a Hollywood star (or perhaps somebody who aspires to be one) showing their Bling $\mathrm{H}_{2} \mathrm{O}$ bottle at award events, parties, etc.

The fourth consumer ritual - divestment, which is linked to the erasure of meanings associated with previous owners or the disposal of a consumer product - might be identified in a few different ways. After finishing with a bottle of water, one might decide to dispose of it, reuse it by refilling it with tap water or even use it as a decorative object at, for example, the office. In the case of the latter, one could say that the divestment ritual links in with the exchange ritual, as the empty or the refilled bottle might provoke or be used to start conversations with friends and colleagues about the ethics of the marketing campaign that is articulated on the bottle's label.

In summary, then, what we are dealing with is the development and articulation of a particular cultural meaning of bottled water that is tightly connected to the symbolism of aid, charity, help and love that is given to poor people and communities in Africa. This affectivity is not artificially attached to the bottled water commodity. What McCracken's (1986) framework helps us to do is to understand how marketing messages are supposed to awaken underlying cultural assumptions in individual consumers, and how they are then completing the process of meaning construction through a range of rituals. For these specific ethical campaigns to function, companies have to de-emphasize the commercial nature of the transaction, as what is being sold is a symbolic meaning that is tightly connected to altruistic images of improving the lives of people. This is why words such as 'buy' were not used in any parts of the campaigns we studied; instead, 'drink,' 'participate,' 'help' and 'love' were all terms used frequently. Beyond the specifics of this case, however, we have to remember that, following Jameson (1991), it is precisely this process of the cultural construction of commodities' meaning that is the very stuff of capitalist reproduction.

\section{Conclusion}

To date, the primary focus of research in the CSR field has been on the strategic implications of CSR for the corporation and less on the effects of CSR on society (Banerjee 2008). What is also under-emphasized is Crouch's (2006) claim that CSR can be seen as a (management) fashion that companies use to improve their 'bottom line.' Equally, Banerjee (2007) and Shamir (2004a) assert that CSR is often no more than an internal or an external marketing practice that is geared towards cementing the role and power of corporate actors, rather than really delivering improvements for people and communities, particularly in the 'developing' world.

In this paper, we have dealt exactly with examples of such 'fashionable' marketing practices that claim to 'do good' for society through CSR strategies. Our particular starting point has been the empirical exploration of these claims through a study of 10 ethical and cause-related marketing campaigns that have been carried out by bottled water companies. We were particularly interested in how companies are able to attach an image of 'ethics,' 'aid,' 'help' and 'development' to a banal, everyday good such as water. We made use of McCracken's (1986) theory of the cultural construction of meaning of consumer goods to show how marketing and advertising campaigns help to turn bottled water into a meaningful, cultural product that is not a mere utilitarian good but a symbolic message about who we, as consumers, are.

We have argued that it is precisely through this process of cultural signification that companies are able to differentiate themselves from their competitors in the hope of gaining an advantage in an increasingly saturated market and distract from attacks on their environmental performance. Instead of addressing these attacks directly - for 


\section{Business Ethics: A European Review}

Volume 20 Number 3 July 2011

example, by reducing the environmental impact of their products - bottled water companies have turned to cause-related marketing in order to improve the image of their brands through 'doing good' in the so-called 'developing world.' That is, the marketing appeal is not directed only at 'ethical' consumers. The practice of 'ethical' consumption is now an invitation extended to all customers, which confirms the findings of the Response (2007) team of researcher who have claimed that 'ethics-in-action' strategies are evidence of a wider shift from a negative conception of CSR (do no harm) to a positive one (do good).

While this shift towards 'ethics-in-action' CSR strategies might be seen as a confirmation of Scherer \& Palazzo's (2007) 'political CSR' framework, emphasizing a tripartite community approach of 'doing good,' we have emphasized the historical struggle that has led to such CSR approaches in the first place. As Fontenelle (2010) argues, the reason why such marketing strategies work in the contemporary marketplace is because customers have increasingly become concerned about the ethics of global capitalism, which has been part of the discursive imagery of many anti-capitalist and antiglobalization movements for the past two decades (Notes from Nowhere 2003). One could argue with Boltanski \& Chiapello (2005) that precisely because of these resistance discourses, which have become a general feature of post-Millennium culture (Gilbert 2008), corporations have had to construct a discursive response in order to maintain their legitimacy as well as their 'bottom line.' That is, because of a general cultural shift towards more 'critical' and 'ethical' questions and concerns expressed about the global impacts of capitalist development, companies have increasingly made use of these new 'ethical' discourses in order to sell their products and services (Littler 2009).

This, we would argue with Jameson (1991), is part of a general process of the reproduction of capitalist modes of accumulation and legitimation that is using cultural categories for its own aims. Our paper has shown exactly how this process works in the specific case of the consumption of 'ethical' bottled water. Our analysis shows that this particular CSR or cause-related marketing approach can be seen as just the latest example of the workings of wider reproductive mechanisms of the hegemony of capitalist accumulation and legitimacy.

\section{References}

Adkins, S. 1999. Cause Related Marketing: Who Cares Wins. Oxford: Butterworth-Heinemann.

Adler, S.M. \& American Marketing Association. 2006. Cause for Concern: Results-Oriented Cause Marketing. Mason, OH: Thomson/South-Western.

Adorno, T.W. 1967. Prisms. London: Spearman.

Applbaum, K. and Jordt, I. 1996. 'Notes toward an application of McCracken's "Cultural Categories" for cross-cultural consumer research'. Journal of Consumer Research, 23:3, 204-218.

Arnould, E. and Thompson, C. 2005. 'Consumer Culture Theory (CCT): twenty years of research'. Journal of Consumer Research, 31:4, 868-882.

Banerjee, S.B. 2007. Corporate Social Responsibility: The Good, the Bad, and the Ugly. Northampton, MA: Edward Elgar.

Banerjee, S.B. 2008. 'Corporate social responsibility: the good, the bad and the ugly'. Critical Sociology, 34:1, 51-79.

Belu. 2010. 'Belu working towards a sustainable future'. Available at http://www.belu.org/ (accessed 2 June 2010).

Bling $\mathrm{H}_{2}$ O. 2006. 'Bling glass bottles'. Available at http://www.blingh2o.com/ (accessed 14 September 2006).

Böhm, S. 2006. 'The carousel event'. In Case, P., Lilley, S. and Owens, T. (Eds.), The Speed of Organization: 199-224. Copenhagen: Copenhagen Business School Press.

Böhm, S. and Batta, A. 2010. 'Just doing it: enjoying commodity fetishism with Lacan'. Organization, 17:3, 345-361.

Böhm, S. and Brei, V. 2008. 'Marketing the hegemony of development: of pulp fictions and green deserts'. Marketing Theory, 8:4, 339-366.

Boltanski, L. and Chiapello, E. 2005. The New Spirit of Capitalism. London: Verso.

Bourdieu, P. 1977. 'The economy of linguistic exchanges'. Social Science Information, 16:6, 645-668.

Bourdieu, P. 1980. Le Sens pratique. Paris: Éditions de Minuit.

Bourdieu, P. 1984. Distinction: A Social Critique of the Judgement of Taste. London: Routledge.

Bourdieu, P. 2000. Les Structures sociales de l'economie. Paris: Éditions du Seuil. 


\section{Business Ethics: A European Review}

Volume 20 Number 3 July 2011

Bourdieu, P. and Delsaut, Y. 1987. 'Le Couturier et sa Griffe: contribution à une théorie de la magie'. Actes de la Recherche en Sciences Sociales, 1, 7-36.

Bourdieu, P. and Wacquant, L. 1992. An Invitation to Reflexive Sociology. Chicago, IL: University of Chicago Press.

Brennan, L. and Binney, W. 2008. 'Is it green marketing, greenwash or hogwash? We need to know if we want to change things'. Partnerships, Proof and Practice - International Nonprofit and Social Marketing Conference, Proceedings, Paper 18. Available at http://ro.uow.edu.au/insm08/18 (accessed 13 June 2010).

Brennan, L. and Binney, W. 2010. 'Fear, guilt, and shame appeals in social marketing'. Journal of Business Research, 63:2, 140-146.

Castaldo, S., Perrini, F., Misani, N. and Tencati, A. 2009. 'The missing link between corporate social responsibility and consumer trust: the case of fair trade products'. Journal of Business Ethics, 84:1, $1-15$.

Crouch, C. 2006. 'Modelling the firm in its market and organizational environment: methodologies for studying corporate social responsibility'. Organization Studies, 27:10, 1533-1551.

Dahlsrud, A. 2008. 'How corporate social responsibility is defined: an analysis of 37 definitions'. Corporate Social Responsibility and Environmental Management, 15:1, 1-13.

Datamonitor. 2009. 'Global bottled water - industry profile'. Available at http://www.datamonitor.com/ store/Product/global_bottled_water?productid $=248$ C4A4A-7D76-4899-B4F3-0E6CACFF95CB (accessed 2 March 2010).

Dolan, C.S. 2005. 'Fields of obligation: rooting ethical sourcing in Kenyan horticulture'. Journal of Consumer Culture, 5:3, 365-389.

Douglas, M. and Isherwood, B. 1996. The World of Goods: Towards an Anthropology of Consumption. Abingdon: Routledge.

Ecologist. 2007. 'Behind the label: Volvic Touch of Fruit'. Available at http://www.theecologist.org/ green_green_living/behind_the_label/269269/behind_ the_label_volvic_touch_of_fruit.html (accessed 7 October 2010).

Ethical Consumer Magazine. 2006. 'Ethical buyer's guide to bottled water'. Ethical Consumer Magazine, Issue 102 (September/October 2006). Available at http://www.ethicalconsumer.org/FreeBuyersGuides/ fooddrink/bottledwater.aspx (accessed 14 February 2010).
Fairclough, N. 1995. Critical Discourse Analysis: The Critical Study of Language. London: Longman.

Fairclough, N. 2003. Analysing Discourse: Textual Analysis for Social Research. London: Routledge.

Fontenelle, I.A. 2010. 'Global responsibility through consumption? Resistance and assimilation in the anti-brand movement'. Critical Perspectives on International Business, 6:4, 256-272.

Foucault, M. 1969. L'Archéologie du savoir. Paris: Gallimard.

Foucault, M. 1971. L'ordre du discours. Paris: Gallimard.

Fox News. 2008. 'Bottled water faces rising tide of criticism'. Fox News. Available at http://www.fox news.com/story/0,2933,389362,00.html (accessed 1 June 2010).

Garriga, E. and Melé, D. 2004. 'Corporate social responsibility theories: mapping the territory'. Journal of Business Ethics, 53:1, 51-71.

Gashler, K. 2008. 'Bottled water's impact on oil use, landfills tough for critics to swallow'. Available at http://www.container-recycling.org/media/newsarti cles/plastic/2008/5-24-NY-BottledWatersImpact.htm (accessed 15 May 2010).

Gilbert, J. 2008. Anticapitalism and Culture. Oxford: Berg.

Goffman, E. 1951. 'Symbols of class status'. British Journal of Sociology, 2:4, 295-304.

Hirschman, E. 1984. 'Leisure motives and sex roles'. Journal of Leisure Research, 16:3, 209-223.

Hirschman, E., Scott, L. and Wells, W.B. 1998. 'A model of product discourse: linking consumer practice to cultural texts'. Journal of Advertising, 27:1, 33-50.

Jameson, F. 1991. Postmodernism, or the Cultural Logic of Later Capitalism. Durham, NC: Duke University Press.

Johnson, A. 2009. 'Drink up (bottled water evolves for a changing market)'. Natural Foods Merchandiser. Available at http://naturalfoodsmerchandiser. com/tabId/66/itemId/3677/Drink-up-bottled-waterevolves-for-a-changing-mar.aspx (accessed 18 May 2010).

Just-Drinks.com. 2008. 'US: Volvic, UNICEF launch initiative for clean water for Africa'. Available at http://www.just-drinks.com/article. aspx $? \mathrm{id}=92700 \&$ $\mathrm{d}=1$ (accessed 27 October 2008).

Klick, M. 2009. 'The political economy of corporate social responsibility and community development: a case study of Norway's Snøhvit Natural Gas Complex'. FNI Report 1/2009. Available at http:// 


\section{Business Ethics: A European Review}

Volume 20 Number 3 July 2011

se1.isn.ch/serviceengine/Files/ISN/103744/ipublica tiondocument_singledocument/75B1FF8B-DECD4E13-9819-CEB209522268/en/FNI-R0109.pdf (accessed 10 May 2010).

Kochan, T. and Rubenstein, S. 2000. 'Toward a stakeholder theory of the firm: the Saturn Partnership'. Organizational Science, 11:4, 367-386.

Kotler, P. and Caslione, J.A. 2009. Chaotics: The Business of Managing and Marketing in the Age of Turbulence. New York, NY: Amacom.

Kotler, P. and Lee, N. 2005. Corporate Social Responsibility: Doing the Most Good for Your Company and Your Cause. Chichester: Wiley.

Laclau, E. and Mouffe, C. 1985. Hegemony and Socialist Strategy. London: Verso.

Levy, S. 1981. 'Interpreting consumer mythology: a structural approach to consumer behavior'. Journal of Marketing, 45:3, 49-61.

Littler, J. 2009. Radical Consumption: Shopping for Change in Contemporary Culture. Maidenhead: Open University Press.

Mandel, E. 1975. Late Capitalism. London: New Left Books.

Marcuse, H. 1964. One Dimensional Man. London: Routledge \& Kegan Paul.

Marcuse, H. 1967. An Essay on Liberation. Harmondsworth: Penguin.

Marx, K. 1976. Capital: A Critique of Political Economy, Vol. 1. London: Penguin.

McCracken, G. 1986. 'Culture and consumption: a theoretical account of the structure and movement of the cultural meaning of consumer goods'. Journal of Consumer Research, 13:1, 71-84.

Miller, D. 1987. Material Culture and Mass Consumption. New York: Blackwell.

Miller, D. 2001. 'The poverty of morality'. Journal of Consumer Culture, 1:2, 225-243.

Mitchell, R.K., Agle, B.R. and Wood, D.J. 1997. 'Toward a theory of stakeholder identification and salience: defining the principle of who and what really counts'. Academy of Management Review, 22:4, 853-886.

Notes from Nowhere (Ed.). 2003. We Are Everywhere: The Irresistible Rise of the Global Anti-Capitalist Movement. London: Verso.

Otto, B. and Böhm, S. 2006. "“The People" and resistance against international business: the case of the Bolivian "Water War"'. Critical Perspectives on International Business, 2:4, 299-320.
Palazzo, G. and Scherer, A.G. 2006. 'Corporate legitimacy as deliberation: a communicative framework'. Journal of Business Ethics, 66:1, 71-88.

Palazzo, G. and Scherer, A.G. 2008. 'The future of global corporate citizenship: towards a new theory of the firm as a political actor'. In Scherer, A.G. and Palazzo, G. (Eds.), Handbook of Research on Global Corporate Citizenship: 577-590. Cheltenham: Edward Elgar.

Phillips, N. and Hardy, C. 2002. Discourse Analysis: Investigating Processes of Social Construction. Thousand Oaks, CA: Sage.

Pringle, H. and Thompson, M. 2001. Brand Spirit: How Cause Related Marketing Builds Brands. Chichester: Wiley.

Response. 2007. 'Understanding and responding to societal demands on corporate responsibility'. Available at http://www.insead.edu/v1/ibis/response_pro ject/documents/Response_FinalReport.pdf (accessed 25 November 2010).

Sahlins, M. 1976. Culture and Practical Reason. Chicago, IL: University of Chicago Press.

Scherer, A.G. and Palazzo, G. 2007. 'Toward a political conception of corporate responsibility business and society seen from a Habermasian perspective'. Academy of Management Review, 32:4, 1096-1120.

Scherer, A.G. and Palazzo, G. 2008. 'Globalization and corporate social responsibility'. In Crane, A., McWilliams, A., Matten, D., Moon, J. and Siegel, D. (Eds.), The Oxford Handbook of Corporate Social Responsibility: 413-431. Oxford: Oxford University Press.

Scherer, A.G. and Palazzo, G. 2011. 'The new political role of business in a globalized world - a review of a new perspective on CSR and its implications for the firm, governance, and democracy'. Journal of Management Studies, 48:4, 899-931.

Shamir, R. 2004a. 'The de-radicalization of corporate social responsibility'. Critical Sociology, 30:3, 669-689.

Shamir, R. 2004b. 'Between self-regulation and the Alien Tort Claims Act: on the contested concept of corporate social responsibility'. Law and Society Review, 38:4, 635-664.

Shamir, R. 2005. 'Corporate social responsibility: a case of hegemony and counter-hegemony'. In Santos, B.S. and Rodriguez-Garavito, C.A. (Eds.), Law and Globalization from Below: 92-117. Cambridge: Cambridge University Press. 


\section{Business Ethics: A European Review \\ Volume 20 Number 3 July 2011}

Snider, J., Hill, R., Ronald, P. and Martin, D. 2003. 'Corporate social responsibility in the 21 st century: a view from the world's most successful firms'. Journal of Business Ethics, 48:2, 175-187.

Spicer, A. and Böhm, S. 2007. 'Moving management: theorizing struggles against the hegemony of management'. Organization Studies, 28:11, 1667-1698.

Steenhaut, S. and Van Kenhove, P. 2006. 'The mediating role of anticipated guilt in consumers' ethical decision-making'. Journal of Business Ethics, 69:3, 269-288.

Trentmann, F. 2009. 'Crossing divides: consumption and globalization in history'. Journal of Consumer Culture, 9:2, 187-220.

Wan-Jan, W.S. 2006. 'Defining corporate social responsibility'. Journal of Public Affairs, 6:3-4, 176-184.

Water for People. 2010. 'Making solutions last'. Available at http://www.waterforpeople.org (accessed 10 June 2010).
Water.org. 2010. 'Water facts'. Available at http:// water.org/learn-about-the-water-crisis/facts/ (accessed 1 May 2010).

Which? 2008. 'Switching from bottled to tap water: Tap vs bottled water'. Available at http://www. which.co.uk/environment-and-saving-energy/environ ment-and-greener-living/guides/switching-from-bottledto-tap-water-/tap-vs-bottled-water/ (accessed 7 October 2008).

World Business Council for Sustainable Development (WBCSD). 2010. 'Business role. Corporate Social Responsibility (CSR)'. Available at http://www. wbcsd.org/templates/TemplateWBCSD5/layout.asp? type $=\mathrm{p} \&$ MenuId $=$ MTE0OQ $($ accessed 5 May 2010).

Williamson, J. 1978. Decoding Advertising. New York: Marion Boyars.

Wymer, W.W. and Samu, S. 2003. Nonprofit and Business Sector Collaboration: Social Enterprises, Cause-Related Marketing, Sponsorships, and Other Corporate-Nonprofit Dealings. New York: Best Business Books. 